\title{
Ocena ekologicznych topników do lutowania twardego w porównaniu z topnikami na bazie boraksu i kwasu borowego
}

\author{
Examination of ecological fluxes to brazing in comparison \\ with boric acid-and borax-based fluxes
}

\begin{abstract}
Streszczenie
W artykule przedstawiono badania właściwości topników ekologicznych będących substytutami topników na bazie kwasu borowego i boraksu, których zastosowanie zostało ograniczone w wyniku wprowadzenia przez Unię Europejską rozporządzenia (WE) 1907/2006-REACH. Przeprowadzono próby zwilżalności i rozpływności przy użyciu lutów twardych Ag 244 i Cu 301 na podstawie, których oceniono wpływ topników ekologicznych na ich właściwości lutownicze. Oceniono również możliwość usuwania pozostałości poszczególnych topników po procesie lutowania. $\mathrm{Na}$ podstawie badań metalograficznych wskazano na niezgodności lutownicze w lutowinie występujące w różnej ilości w zależności od użytego topnika.
\end{abstract}

Słowa kluczowe: topniki ekologiczne; boraks; kwas borowy; zwilżalność; rozpływność; lutowanie twarde

\begin{abstract}
Tested and analyzed properties of ecological fluxes, substitutes of boric acid- and borax-based fluxes, were presented in the article. The application of boric acidand borax-based fluxes was limited as a result of the regulation (WE) 1907/2006-REACH adopted by the European Union. The wettability and spreadability tests were run with use of $\mathrm{Ag} 244$ and $\mathrm{Cu} 301$ brazes. The influence of eco-fluxes on braze properties and the possibility of removing the remains of particular fluxes after brazing process were examined basing on the tests. According to the metallography tests the imperfections in braze were pointed out. The amount of the imperfections appearing in the braze varied depending on the type of the applied flux.
\end{abstract}

Keywords: ecological fluxes; borax; boric acid; wettability; spreadability; brazing

\section{Wstęp}

W grudniu 2006 r. Parlament Europejski wprowadził rozporządzenie (WE) 1907/2006 w sprawie rejestracji, oceny, udzielania zezwoleń i stosowanych ograniczeń w zakresie chemikaliów (REACH) i utworzenia Europejskiej Agencji Chemikaliów [5]. Badania przeprowadzone przez Radę Europy wykazały, że produkty zawierające kwas borowy i boraks (sole boranu sodowego) są szkodliwe dla zdrowia i mogą stanowić zagrożenie dla układu rozrodczego oraz prawidłowego rozwoju płodu ludzkiego. Ponadto ich opary działają drażniąco na oczy i drogi oddechowe [12]. W związku, z czym boraks i kwas borowy zostały przekwalifikowane do kategorii 2 obejmującej środki „działające szkodliwie na rozrodczość". Restrykcje dotyczą również topników lotnych, będących mieszaniną boranu trimetylu (50-80\% wag.) $z$ alkoholem metylowym, stosowanych $m$. in. do lutowania różnego rodzaju instalacji rurowych [12:14]. Produkty zawierające boraks i/lub kwas borowy oraz topniki lotne na bazie związków boru muszą być oznaczane jako produkty toksyczne [12]. Wprowadzone regulacje wchodzą w życie od 1 sierpnia 2016 r., a producenci zobowiązani są całkowicie wycofać z produkcji produkty lutownicze zawierające boraks i kwas borowy w ciągu 27 miesięcy od tej daty [15].

Wprowadzone restrykcje wymusiły na producentach materiałów lutowniczych konieczność opracowania nowych, ekologicznych topników do lutowania twardego, mogących skutecznie zastąpić powszechnie stosowane topniki oparte na boraksie i kwasie borowym. Jest to szczególnie ważne dla topnikowego lutowania twardego spoiwami na osnowie miedzi, które w kraju jest szeroko stosowane w przemyśle [16-18].

Prof. dr hab. inż. Zbigniew Mirski, dr inż. Tomasz Wojdat, Agata Borzestowska - Politechnika Wrocławska.

Autor korespondencyjny/Corresponding author. zbigniew.mirski@pwr.edu.pl 
Zadaniem topników jest usunięcie tlenków powstających na powierzchni łączonych metali oraz ciekłego lutu podczas ich nagrzewania w procesie lutowania. Wybór topnika uzależniony jest przede wszystkim od rodzaju lutowanego materiału, stosowanego spoiwa oraz metody lutowania. Dzięki działaniu topnika lut może zwilżać i swobodnie rozpływać się po powierzchni łączonych metali oraz wnikać i wypełniać szczeliny kapilarne $[1 \div 4]$.

Topniki na bazie kwasu borowego $\left(\mathrm{H}_{3} \mathrm{BO}_{3}\right)$ i boraksu (czteroboran sodu $\mathrm{Na}_{2} \mathrm{~B}_{4} \mathrm{O}_{7}$ ), występujące najczęściej w postaci proszku lub past lutowniczych, stosowane są do lutowania twardego stali niestopowych i stopowych, miedzi i jej stopów oraz żeliwa, przy użyciu lutów na osnowie miedzi i srebra $[1,3]$. Przez wiele lat były/są one stosowane w różnych dziedzinach przemysłu np. do lutowania elementów wymienników ciepła lub kształtek z węglików spiekanych ze stalowymi korpusami w przemyśle narzędziowym [1].

Temperatura topnienia kwasu borowego wynosi $577^{\circ} \mathrm{C}$, zaś boraksu $741{ }^{\circ} \mathrm{C}$ [4]. Często w praktyce stosuje się mieszaniny boraksu i kwasu borowego, które charakteryzują się większą aktywnością chemiczną. Podczas procesu lutowania przebiega rekcja chemiczna, w wyniku której z obydwu składników powstaje trójtlenek boru $\mathrm{B}_{2} \mathrm{O}_{3}$. W ten sposób wytwarza się żużel z zasadowymi tlenkami metali. Zaletą żużla potopnikowego jest hamowanie dalszego utleniania powierzchni metalu. Z powodu silnie przylegającej szklistej powłoki jest on najczęściej usuwany mechanicznie obróbką strumieniowo-ścierną [1].

\section{Materiały dodatkowe}

Przeprowadzone badania dotyczyły określenia właściwości lutowniczych topników ekologicznych w porównaniu z topnikiem na bazie boraksu i kwasu borowego. W tym celu przeprowadzono próby zwilżalności i rozpływności, badania metalograficzne złączy lutowanych oraz dokonano oceny sposobu usuwania żużla potopnikowego.

Wybrano dwa rodzaje topników ekologicznych o oznaczeniu Eco Smart Color Change i Eco Smart High Heat, produkowane przez firmę Harris Calorific International $[6,11]$, które porównano z topnikiem na bazie boraksu i kwasu borowego, o umownym oznaczeniu TBB stosowanym w dalszej części artykułu (tabl. I). Topniki ekologiczne nie zawierają kwasu borowego ani boraksu, a więc składników będących przedmiotem restrykcji UE, posiadają certyfikat topników przyjaznych dla środowiska. Przeznaczone są do lutowania stali niestopowych, stali nierdzewnej, niklu, miedzi, mosiądzu, brązu oraz innych metali i stopów żelaznych i nieżelaznych przy użyciu spoiw srebrnych i mosiężnych $[6,11]$.

Topnik Eco Smart Color Change zmienia kolor podczas nagrzewania z intensywnie zielonego na przezroczysty,
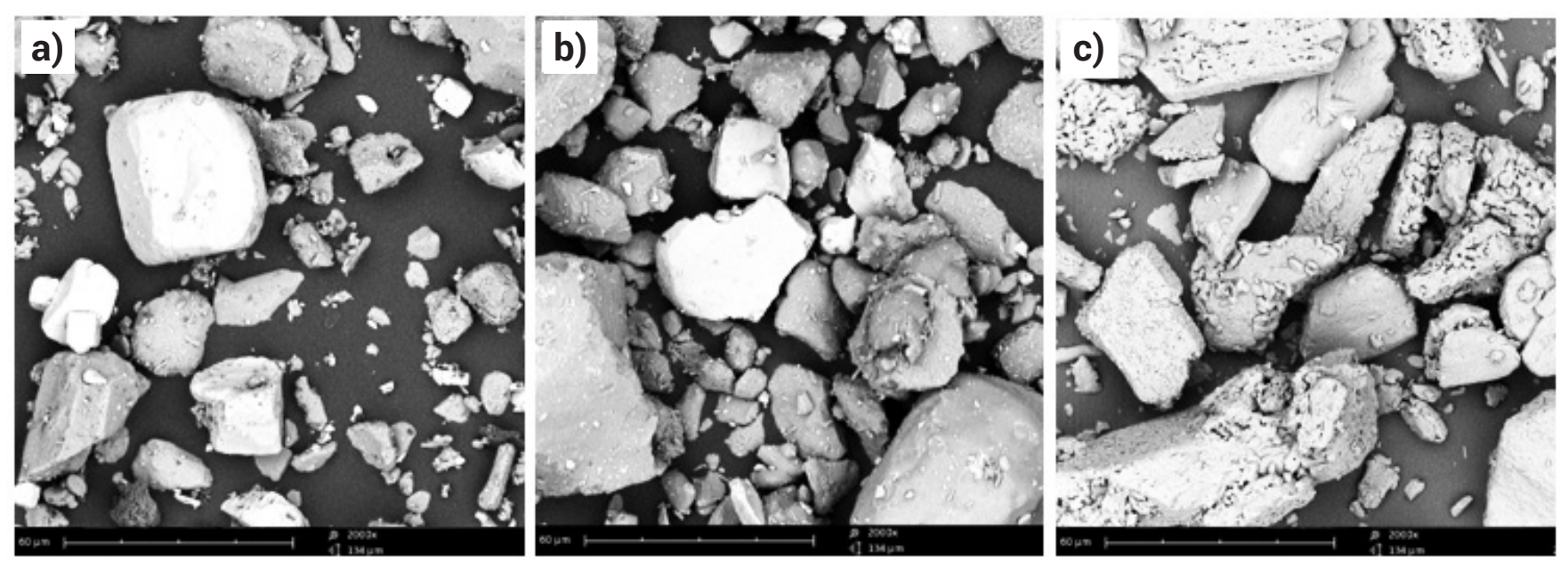

Rys. 1. Widok proszków badanych topników: a) Eko Smart Color Change, b) Eko Smart High Heat, c) TBB

Fig. 1. The view of powders tested fluxes: a) Eco Smart Color Change, b) Eco Smart High Heat, c) TBB

Tablica I. Baza chemiczna i temperatura aktywności badanych topników [6,7]

Table I. Chemical base and the temperature activity of tested fluxes $[6,7]$

\begin{tabular}{|c|c|c|c|}
\hline Lp. & Oznaczenie & Baza chemiczna & Temperatura aktywności, ${ }^{\circ} \mathrm{C}$ \\
\hline 1. & TBB & boraks, kwas borowy & $700 \div 1050$ \\
\hline 2. & Eco Smart Color Change & \multirow{2}{*}{$\begin{array}{l}\text { difluorodihydroksyboran potasu, } \\
\text { fluoroboran potasu, krzemionka } \\
\text { koloidalna }\end{array}$} & $427 \div 871$ \\
\hline 3. & Eco Smart High Heat & & $371 \div 982$ \\
\hline
\end{tabular}

Tablica II. Skład chemiczny i temperatura topnienia lutu srebrnego i mosiężnego (wg PN-EN ISO 17672:2010)

Table II. The chemical composition and the melting point of silver and brass solder (acc. to PN-EN ISO 17672:2010)

\begin{tabular}{|c|c|c|c|c|c|}
\hline \multirow{2}{*}{ Spoiwo } & \multicolumn{4}{|c|}{ Skład chemiczny, \% wag. } & \multirow{2}{*}{$\begin{array}{l}\text { Temperature } \\
\text { topnienia, }{ }^{\circ} \mathrm{C}\end{array}$} \\
\hline & $\mathrm{Ag}$ & $\mathrm{Cu}$ & $\mathrm{Zn}$ & Inne & \\
\hline $\mathrm{Ag} 244$ & $43,0 \div 45,0$ & $29,0 \div 31,0$ & $24,0 \div 28,0$ & Sn max. 2,0 & $675 \div 735$ \\
\hline Cu 301 & - & $58,1 \div 61,5$ & $38,1 \div 41,5$ & Si $0,2 \div 0,4$ & $875 \div 895$ \\
\hline
\end{tabular}


informując lutowacza, że topnik staje się aktywny i następuje rozpuszczanie warstw tlenkowych znajdujących się na powierzchni materiałów lutowanych. Szeroki zakres temperatury aktywności pozwala na używanie go przy użyciu dużej grupy lutów twardych $[6,11]$. Z kolei topnik Eco Smart High Heat ma jeszcze bardziej rozszerzony zakres temperatury aktywności oraz wydłużony czas działania. Można, zatem stosować go do dłuższych procesów lutowania, przy użyciu jeszcze większej grupy lutów twardych $[6,11]$. Topnik na bazie boraksu i kwasu borowego zalecany jest do lutowania w wysokiej temperaturze z użyciem spoiw mosiężnych. Wykazuje temperaturę aktywności w zakresie $750 \div 1050{ }^{\circ} \mathrm{C}$, a zalecana temperatura pracy wynosi $800 \div 1000{ }^{\circ} \mathrm{C}$. Badane topniki były w postaci proszku o podobnym (nieregularnym) kształcie i wielkości ziaren (rys. 1), a bezpośrednio przed lutowaniem mieszano je $z$ wodą destylowaną do uzyskania konsystencji pasty.

W celach porównawczych do prób wybrano dwa rodzaje lutów twardych: na osnowie srebra o oznaczeniu Ag 244 i na osnowie miedzi - Cu 301. Skład chemiczny i temperaturę topnienia wybranych spoiw lutowniczych zamieszczono w tablicy II.

Lut srebrny Ag 244 ma niższą temperaturę topnienia od temperatury aktywności topnika na bazie boraksu i kwasu borowego, dlatego nie powinien być on stosowany w połączeniu z nim w procesie lutowania. Według przyjętej zasady topnik powinien wykazywać temperaturę aktywności niższą o ok. $20 \div 50{ }^{\circ} \mathrm{C}$ od temperatury topnienia lutu, aby przygotować (oczyścić) powierzchnię do lutowania. Pomimo to, w celach porównawczych, wykonano próby lutowania, w których stosowano lut Ag 244 w połączeniu z topnikiem TBB, żeby wykazać ewentualne nieprawidłowości wynikające z niewłaściwego zestawienia materiałów dodatkowych.

Porównawcze próby zwilżalności i rozpływności przeprowadzono na dwóch różnych materiałach - na podłożu miedzianym (Cu-ETP) i stalowym (S235JR). Natomiast do wykonania połączeń przeznaczonych do badań metalograficznych użyto tylko stali gat. S235JR.

\section{Próby rozpływności i zwilżalności}

Do przeprowadzenia prób rozpływności i zwilżalności zastosowano luty twarde Ag 244 oraz Cu 301 o średnicy $2 \mathrm{~mm}$, które pocięto na krótkie odcinki, których masa wynosiła 0,2 g. Następnie przy użyciu strzykawki pokryto je topnikiem o takiej samej masie. Wymiary próbek przeznaczonych do badań wynosiły: powierzchnia 50x50 mm, grubość $0,5 \mathrm{~mm}$. Przed wykonaniem prób podłoża zostały oczyszczone włókniną ścierną i odtłuszczone. Próbki lutowano płomieniowo, nagrzewając je od góry (a nie od dołu, jak często ma to miejsce przy tego rodzaju próbach), żeby odzwierciedlić rzeczywiste warunki procesu lutowania. Palnik wyregulowano tak, aby uzyskać płomień acetylenowo-tlenowy z lekkim nadmiarem gazu palnego. W celu zapewnienia powtarzalnych parametrów lutowania
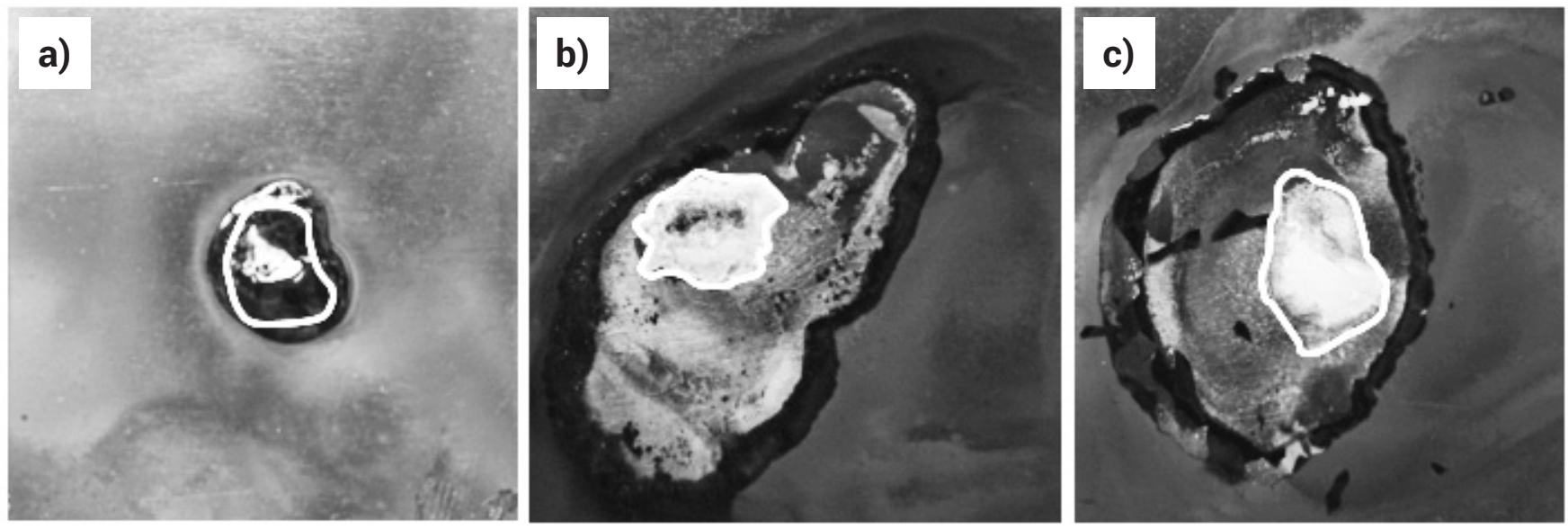

Rys. 2. Przykładowe krople rozpłyniętego lutu Cu 301 na podłożu S235JR wraz z pozostałościami topników: a) TBB, b) Eco Smart Color Change, c) Eco Smart High Heat

Fig. 2. Illustrative surface areas drops of $\mathrm{Cu} 301$ braze on the substrate S235JR and residue flux: a) TBB, b) Eco Smart Color Change, c) Eco Smart High Heat (c)

Tablica III. Usuwanie pozostałości topników po procesie lutowania

Table III. Removal of flux residue after the brazing process

\begin{tabular}{|c|c|c|c|c|}
\hline \multirow{2}{*}{ Lp. } & \multirow{2}{*}{ Topnik } & \multicolumn{2}{|c|}{ Lut } & \multirow{2}{*}{ Uwagi } \\
\hline & & Ag 244 & Cu 301 & \\
\hline 1. & TBB & * & * & $\begin{array}{l}\text { szklista, trudno rozpuszczalna w wodzie powłoka - wymagana do- } \\
\text { datkowa obróbka }\end{array}$ \\
\hline 2. & $\begin{array}{l}\text { Eco Smart Color } \\
\text { Change }\end{array}$ & $\star \star \star *$ & ** & $\begin{array}{l}\text { szklista, rozpuszczalna w wodzie powłoka, trudna do usunięcia } \\
\text { w przypadku osiągnięcia górnej temperatury pracy topnika }\end{array}$ \\
\hline 3. & $\begin{array}{l}\text { Eco Smart High } \\
\text { Heat }\end{array}$ & 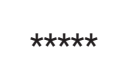 & $\star \star \star \star *$ & $\begin{array}{l}\text { łatwo zmywalny wodą żużel, nawet podczas stosowania z lutami } \\
\text { o wysokiej temperaturze topnienia }\end{array}$ \\
\hline
\end{tabular}


(taki sam rodzaj i właściwości płomienia) używano palnika z funkcją oszczędzacza gazu, firmy Harris, model 50-9 $[6,11]$. Czas nagrzewania od momentu stopienia się lutu wynosił $5 \mathrm{~s}$.

Po zakończeniu procesu lutowania dokonano oceny usuwania żużla potopnikowego z powierzchni próbek przeznaczonych do badań rozpływności. Na rysunku 2 pokazano widok przykładowych próbek bezpośrednio po procesie lutowania z pozostałościami poszczególnych topników.

Pozostałości topnika na bazie boraksu i kwasu borowego (TBB) tworzą w miejscu jego oddziaływania szklistą powłokę, która jest trudno zmywalna wodą, przez co ich usunięcie jest utrudnione i wymaga stosowania dodatkowej obróbki. Znacznie trudniej usuwa się pozostałości tego topnika ze złączy wykonanych przy użyciu lutu mosiężnego Cu 301 niż srebrnego $\mathrm{Ag}$ 244. Spowodowane jest to wyższą temperaturą procesu topnik jest aktywny przez dłuższy czas, przez co jego pozostałości są bardziej nasycone tlenkami i przyczepne do podłoża, a tym samym trudniejsze do usunięcia.

W przypadku topnika Eco Smart Color Change jego pozostałości $w$ porównaniu pozostałościami topnika TBB są znacznie łatwiejsze do usunięcia. Na powierzchni również tworzy się szklista powłoka, ale jest ona zmywalna wodą i daje się stosunkowo łatwo usunąć bez stosowania dodatkowych zabiegów. Również łatwiej jest ją usunąć, gdy temperatura lutowania jest niższa, czyli z połączeń wykonanych spoiwami srebrnymi.

Najłatwiejsze do usunięcia spośród wszystkich badanych topników są pozostałości topnika Eco Smart High Heat. Jest to spowodowane jego szerokim zakresem tem-

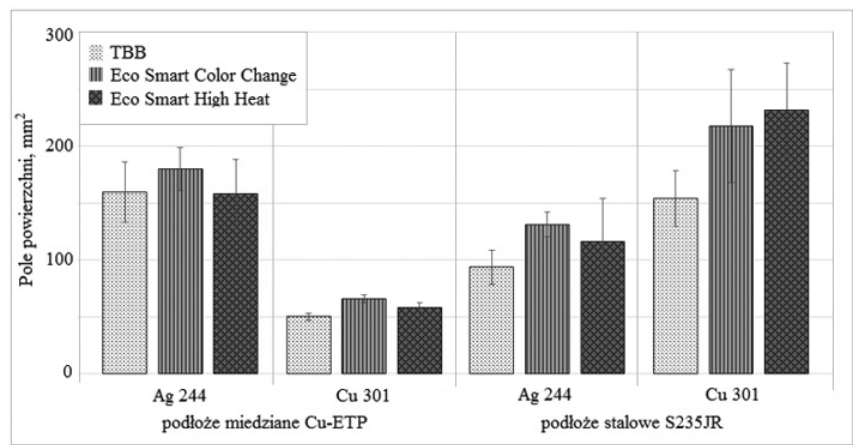

Rys. 3. Pole rozpływności lutów w zależności od rodzaju topnika i podłoża

Fig. 3. Brazes surface areas depending on the flux and substrate type

Tablica IV. Wyniki pomiarów rozpływności lutów Ag 244 i Cu 301

Table IV. Results of measurements of spreadability Ag 244 and Cu 301 brazes

\begin{tabular}{|c|c|c|c|c|c|c|}
\hline \multirow[b]{3}{*}{ Topnik } & \multirow[b]{3}{*}{ Lut } & \multirow[b]{3}{*}{ Nr próbki } & \multicolumn{4}{|c|}{ Podłoże } \\
\hline & & & \multicolumn{2}{|c|}{ Cu-ETP } & \multicolumn{2}{|c|}{ Stal S235JR } \\
\hline & & & $\begin{array}{c}\text { Pole } \\
\text { powierzchni } \\
\text { rozpływności } \\
{\left[\mathrm{mm}^{2}\right]}\end{array}$ & $\begin{array}{c}\text { Średnie pole } \\
\text { powierzchni } \\
\text { rozpływności } \\
{\left[\mathrm{mm}^{2}\right]}\end{array}$ & $\begin{array}{c}\text { Pole } \\
\text { powierzchni } \\
\text { rozpływności } \\
{\left[\mathrm{mm}^{2}\right]}\end{array}$ & $\begin{array}{c}\text { Średnie pole } \\
\text { powierzchni } \\
\text { rozpływności } \\
{\left[\mathrm{mm}^{2}\right]}\end{array}$ \\
\hline \multirow{6}{*}{ TBB } & \multirow{3}{*}{ Ag 244} & 1 & 181 & \multirow{3}{*}{160} & 110 & \multirow{3}{*}{94} \\
\hline & & 2 & 130 & & 80 & \\
\hline & & 3 & 169 & & 91 & \\
\hline & \multirow{3}{*}{ Cu 301} & 1 & 47 & \multirow{3}{*}{50} & 171 & \multirow{3}{*}{154} \\
\hline & & 2 & 51 & & 165 & \\
\hline & & 3 & 53 & & 126 & \\
\hline \multirow{6}{*}{$\begin{array}{c}\text { Eco Smart } \\
\text { Color Change }\end{array}$} & \multirow{3}{*}{ Ag 244} & 1 & 192 & \multirow{3}{*}{180} & 129 & \multirow{3}{*}{131} \\
\hline & & 2 & 158 & & 122 & \\
\hline & & 3 & 190 & & 143 & \\
\hline & \multirow{3}{*}{ Cu 301} & 1 & 69 & \multirow{3}{*}{66} & 176 & \multirow{3}{*}{218} \\
\hline & & 2 & 62 & & 205 & \\
\hline & & 3 & 67 & & 273 & \\
\hline \multirow{6}{*}{$\begin{array}{l}\text { Eco Smart } \\
\text { High Heat }\end{array}$} & \multirow{3}{*}{ Ag 244} & 1 & 183 & \multirow{3}{*}{158} & 121 & \multirow{3}{*}{117} \\
\hline & & 2 & 124 & & 152 & \\
\hline & & 3 & 167 & & 77 & \\
\hline & \multirow{3}{*}{ Cu 301} & 1 & 59 & \multirow{3}{*}{59} & 256 & \multirow{3}{*}{232} \\
\hline & & 2 & 55 & & 184 & \\
\hline & & 3 & 62 & & 255 & \\
\hline
\end{tabular}



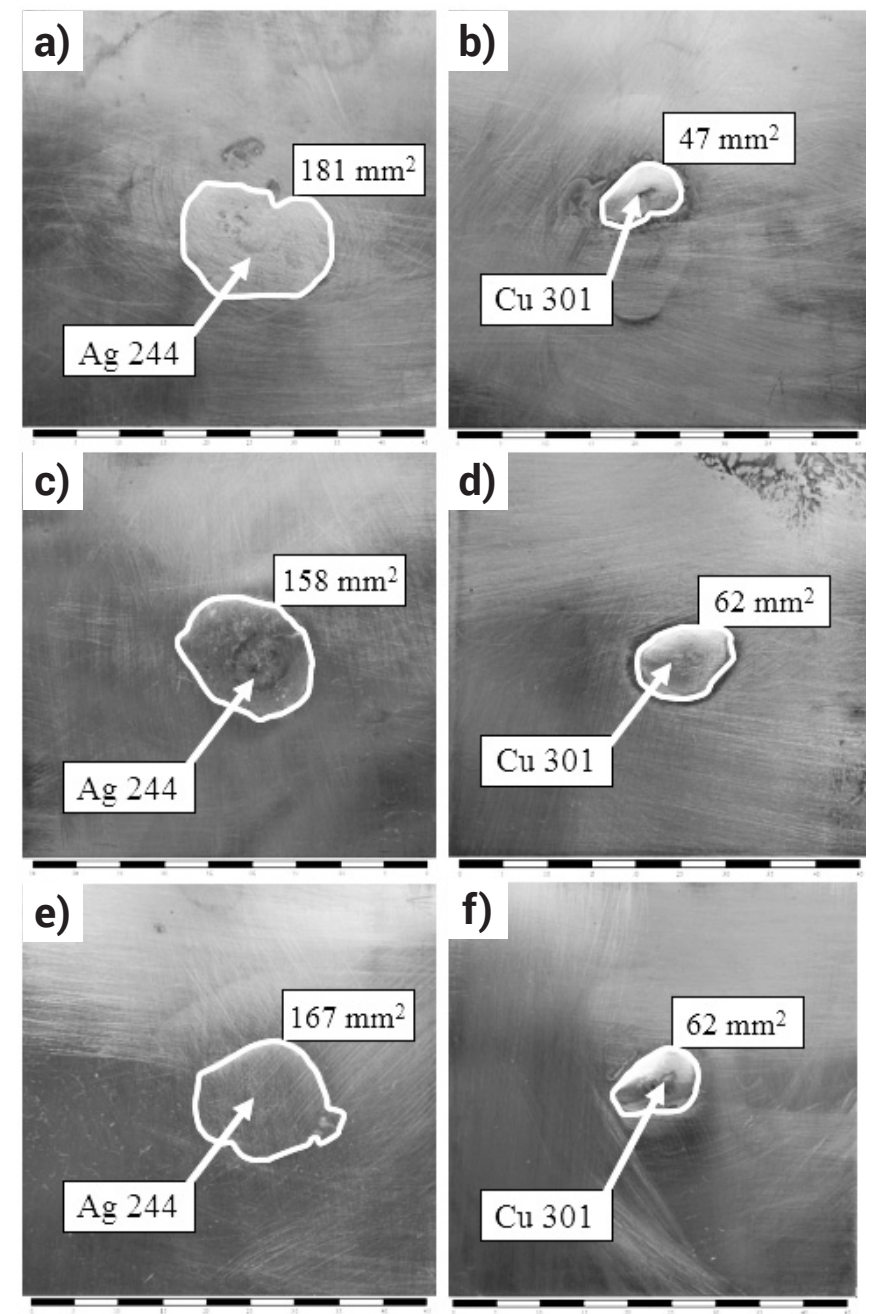

Rys. 4. Przykładowe pola rozpływności lutów twardych na podłożu miedzianym z użyciem topnika: a) i b) TBB, c) i d) Eco Smart Color Change, e) i f) Eco Smart High Heat

Fig. 4. Illustrative surface areas of spreadability of brazes on the copper surface with use of flux: a) and b) TBB, c) and d) Eco Smart Color Change, e) and f) Eco Smart High Heat

peratury aktywności oraz wydłużonym czasem działania, przez co nie ulega on szybkiej degradacji. Pozostałości topnika nie tworzą szklistej powłoki i są łatwo zmywalne wodą.

W tablicy III przedstawiono ocenę usuwania pozostałości topników wybranych do badań po procesie lutowania w zależności od rodzaju użytego spoiwa, w odniesieniu do 5-cio stopniowej skali.

Po oczyszczeniu z pozostałości topnika wszystkie próbki sfotografowano, aby przeprowadzić pomiary pól powierzchni rozpływności. Do tego celu użyto program DP-Soft Olympus do cyfrowej obróbki zdjęć mający funkcję planimetrowania powierzchni. Wyniki pomiarów rozpływności na podłożu miedzianym i stalowym z użyciem badanych topników TBB, Eco Smart Color Change i Eco Smart High Heat zestawiono w tablicy IV i pokazano na rysunku 3 . Widok wybranych pół powierzchni rozpływności pokazano na rysunkach 4 i 5 .

Na podłożu miedzianym większą rozpływność wykazuje lut Ag 244. Największą średnią powierzchnię rozpływności, równą $180 \mathrm{~mm}^{2}$, uzyskano przy użyciu topnika Eco Smart Color Change. Rozpatrując natomiast podłoże stalowe większą rozpływnością charakteryzuje się lut na osnowie miedzi. Zastosowanie topnika Eco Smart High Heat umożliwiło uzyskanie największego średniego pola powierzchni rozpływności wynoszącego $232 \mathrm{~mm}^{2}$.

Do wyznaczenia kątów zwilżania, próbki przecięto w połowie rozpłyniętej kropli lutu i przygotowano zgłady metalo-
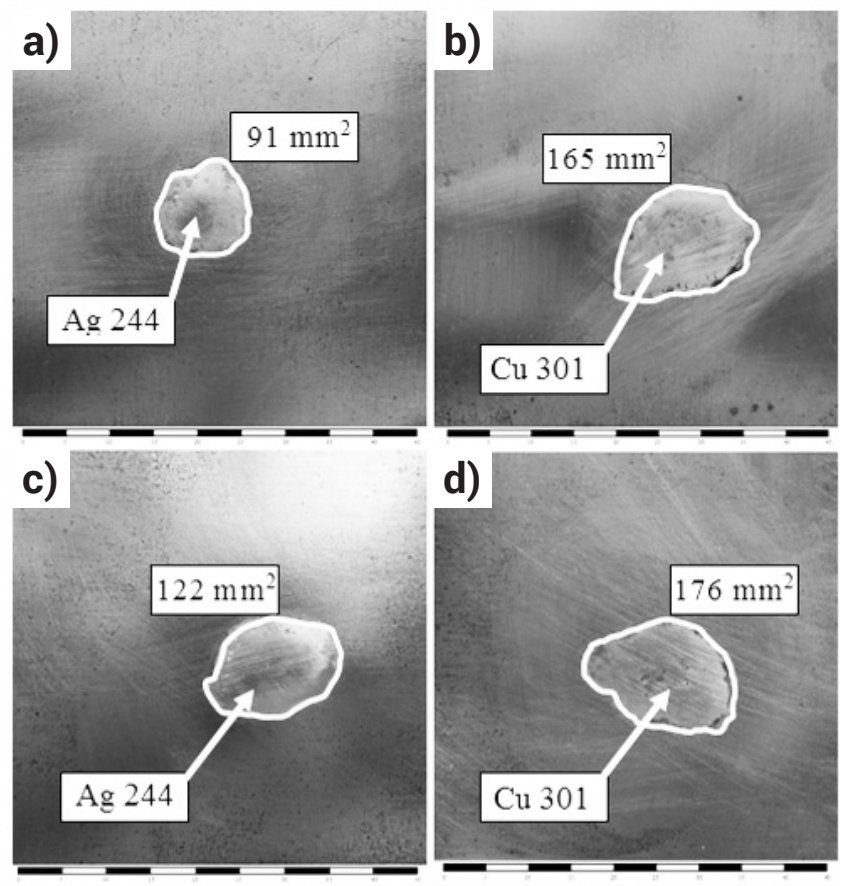

d)
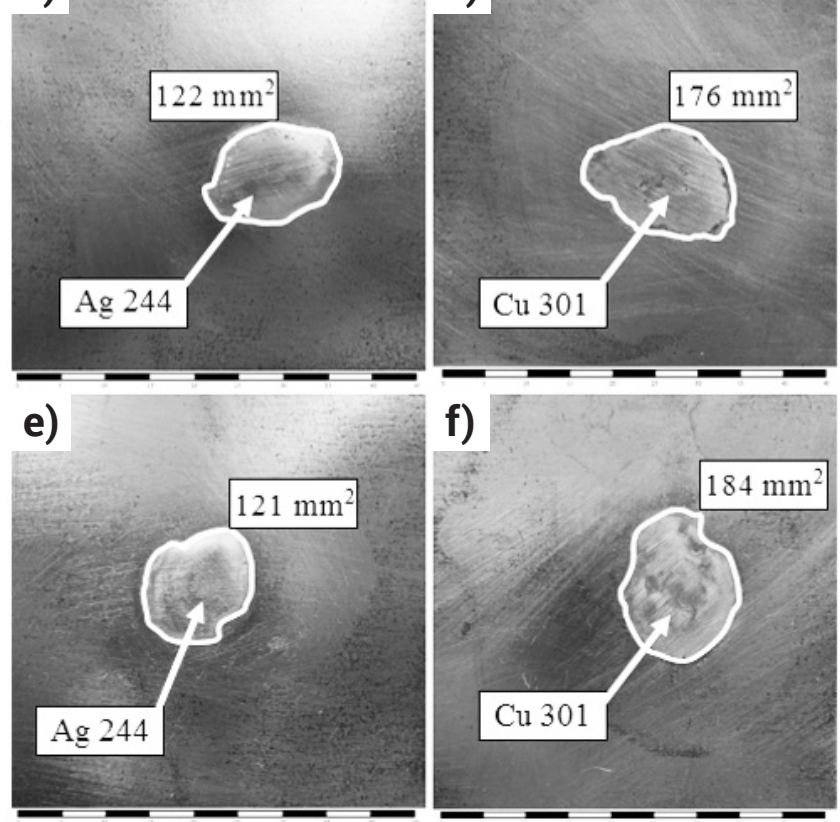

Rys. 5. Przykładowe pola rozpływności lutów twardych na podłożu stalowym z użyciem topnika: a) i b) TBB, c) i d) Eco Smart Color Change, e) if) Eco Smart High Heat)

Fig. 5. Illustrative surface areas of spreadability of brazes on the copper surface with use of flux: a) and b) TBB, c) and d) Eco Smart Color Change, e) and f) Eco Smart High Heat

graficzne, które następnie obserwowano pod mikroskopem świetlnym firmy Olympus, sprzężonym z kamerą i programem ToupView. Umożliwiło to graficzne wyznaczenie kątów zwilżania poszczególnych próbek. W tablicy $\vee$ zamieszczono wartości kątów zwilżania oraz obliczone wartości średnie. Wartość kąta zwilżania $\theta$ podana w tablicy $\mathrm{V}$ jest wartością średnią z pomiarów z lewej i prawej strony kropli lutu. Wyniki przedstawione zostały dodatkowo na wykresie (rys. 6). Przykładowe zwilżanie lutami Ag 244 i Cu 301 podłoża miedzianego i stalowego przedstawiono odpowiednio na rysunku 7 oraz 8.

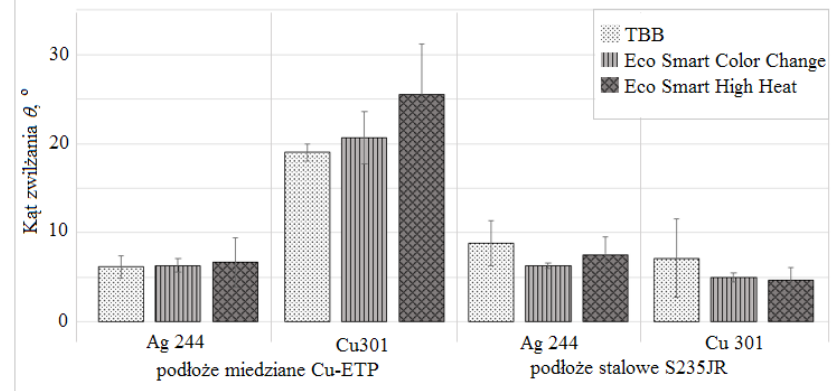

Rys. 6. Zwilżalność miedzi i stali w zależności od rodzaju lutu i topnika Fig. 6. The wettability of copper and steel, depending on the braze and flux type 
Tablica V. Wyniki pomiarów rozpływności lutów Ag 244 i Cu 301

Table V. Results of measurements of spreadability Ag 244 and Cu 301 brazes

\begin{tabular}{|c|c|c|c|c|c|c|}
\hline \multirow[b]{2}{*}{ Topnik } & \multirow[b]{2}{*}{ Lut } & \multirow[b]{2}{*}{ Nr próbki } & \multicolumn{2}{|c|}{ Podłoże miedziane CU-ETP } & \multicolumn{2}{|c|}{ Podłoże stalowe S235JR } \\
\hline & & & $\begin{array}{c}\text { Kąt zwilżania } \\
\theta\left[^{\circ}\right]\end{array}$ & $\begin{array}{c}\text { Średni kąt } \\
\text { zwilżania } \theta\left[^{\circ}\right]\end{array}$ & $\begin{array}{c}\text { Kąt zwilżania } \\
\theta\left[^{\circ}\right]\end{array}$ & $\begin{array}{c}\text { Średni kąt } \\
\text { zwilżania } \theta\left[^{\circ}\right]\end{array}$ \\
\hline \multirow{6}{*}{ TBB } & \multirow{3}{*}{ Ag 244} & 1 & 5,0 & \multirow{3}{*}{6,2} & 6,0 & \multirow{3}{*}{8,8} \\
\hline & & 2 & 6,0 & & 11,0 & \\
\hline & & 3 & 7,5 & & 9,5 & \\
\hline & \multirow{3}{*}{ Cu 301} & 1 & 18,0 & \multirow{3}{*}{19,0} & 6,0 & \multirow{3}{*}{7,2} \\
\hline & & 2 & 20,0 & & 3,5 & \\
\hline & & 3 & 19,0 & & 12,0 & \\
\hline \multirow{6}{*}{$\begin{array}{l}\text { Eco Smart } \\
\text { Color Change }\end{array}$} & \multirow{3}{*}{ Ag 244} & 1 & 6,5 & \multirow{3}{*}{6,3} & 6,5 & \multirow{3}{*}{6,3} \\
\hline & & 2 & 7,0 & & 6,5 & \\
\hline & & 3 & 5,5 & & 6,0 & \\
\hline & \multirow{3}{*}{ Cu 301} & 1 & 24,0 & \multirow{3}{*}{20,7} & 4,5 & \multirow{3}{*}{5,0} \\
\hline & & 2 & 19,0 & & 5,5 & \\
\hline & & 3 & 19,0 & & 5,0 & \\
\hline \multirow{6}{*}{$\begin{array}{l}\text { Eco Smart } \\
\text { High Heat }\end{array}$} & \multirow{3}{*}{ Ag 244} & 1 & 6,5 & \multirow{3}{*}{6,7} & 7,5 & \multirow{3}{*}{7,5} \\
\hline & & 2 & 9,5 & & 5,5 & \\
\hline & & 3 & 4,0 & & 9,5 & \\
\hline & \multirow{3}{*}{ Cu 301} & 1 & 29,5 & \multirow{3}{*}{25,5} & 3,0 & \multirow{3}{*}{4,7} \\
\hline & & 2 & 19,0 & & 5,5 & \\
\hline & & 3 & 28,0 & & 5,5 & \\
\hline
\end{tabular}

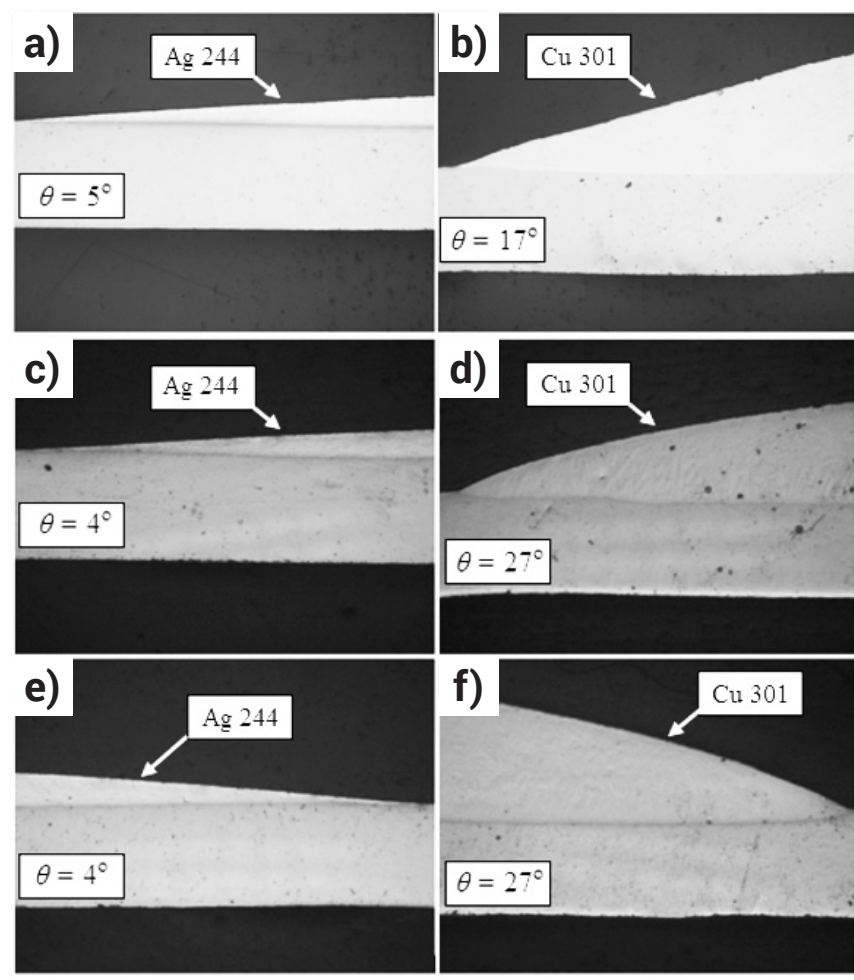

Rys. 7. Zwilżalność lutów twardych na podłożu miedzianym przy użyciu topnika: a) i b) TBB, c) i d) Eco Smart Color Change, e) i f) Eco Smart High Heat

Fig. 7. Wettability of brazes on the copper surface with use of flux: a) and b) TBB, c) and d) Eco Smart Color Change, e) and f) Eco Smart High Heat

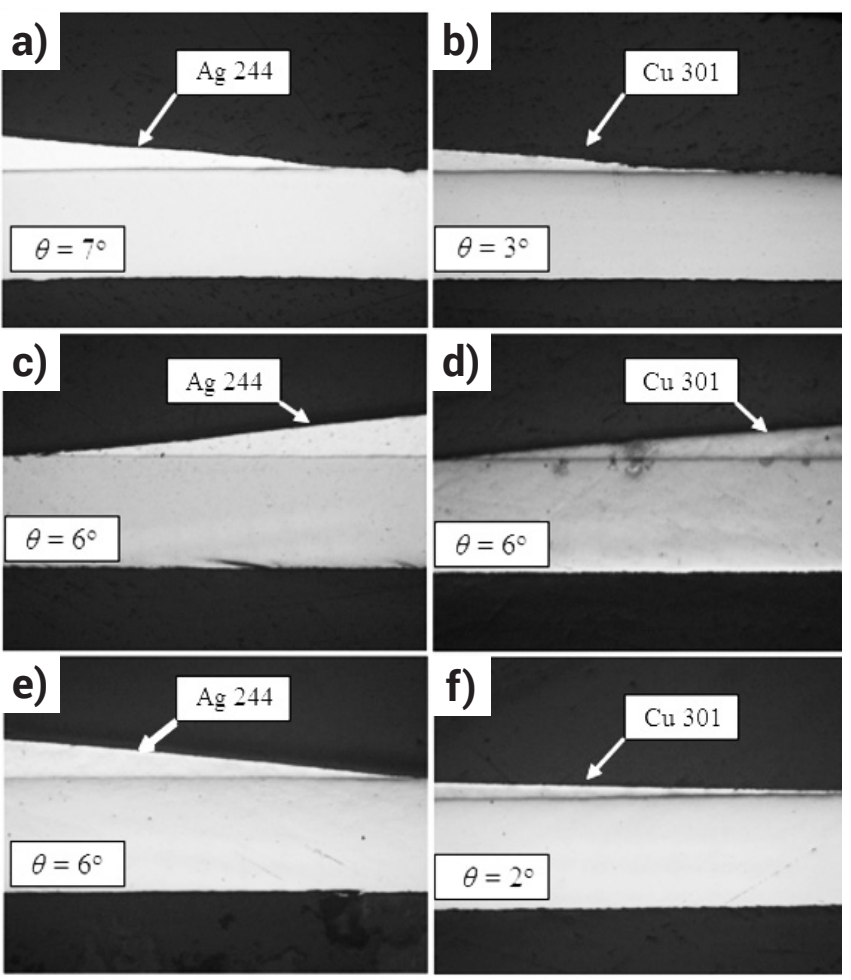

Rys. 8. Zwilżalność lutów twardych na podłożu stalowym przy użyciu topnika: a) i b) TBB, c) i d) Eco Smart Color Change, e) i f) Eco Smart High Heat)

Fig. 8. Wettability of brazes on the steel surface with use of flux: a) and b) TBB, c) and d) Eco Smart Color Change, e) and f) Eco Smart High Heat 
Badania zwilżalności lutów Ag 244 i Cu 301 na podłożu miedzianym i stalowym przy użyciu topników ekologicznych wykazały, że spełniają one warunki dobrej lutowności. Kąty zwilżania nie przekraczają $30^{\circ}$. Zwilżalność lutu na osnowie srebra na podłożu miedzianym jest o wiele lepsza, niż lutu na bazie miedzi i wynosi średnio $7^{\circ}$. Najlepszą zwilżalność osiągnięto dla lutu Cu 301 na podłożu stalowym, zarówno z użyciem topnika Eco Smart Color Change, jak i Eco Smart High Heat. W obydwu przypadkach średni kąt zwilżania wynosił $5^{\circ}$.

\section{Badania metalograficzne}

Badania metalograficzne przeprowadzono w celu sprawdzenia, czy w zależności od rodzaju użytego topnika, w lutowinie po procesie lutowania pozostają niezgodności lutownicze tj. pozostałości żużla potopnikowego i/lub pęcherze gazowe. Przygotowano dwa rodzaje złączy lutowanych - zakładkowe (rys. 9a) i złącze z otworem nieprzelotowym (rys. 9b) tzw. złącze nietechnologiczne (zamknięte bez przejścia topnika i lutu na drugą stronę połączenia). Złącza z otworem nieprzelotowym stosowane są $m$. in. w produkcji narzędzi górniczych np. noży promieniowych ze słupkami węglikowymi do kombajnów pracujących w kopalniach węgla kamiennego.
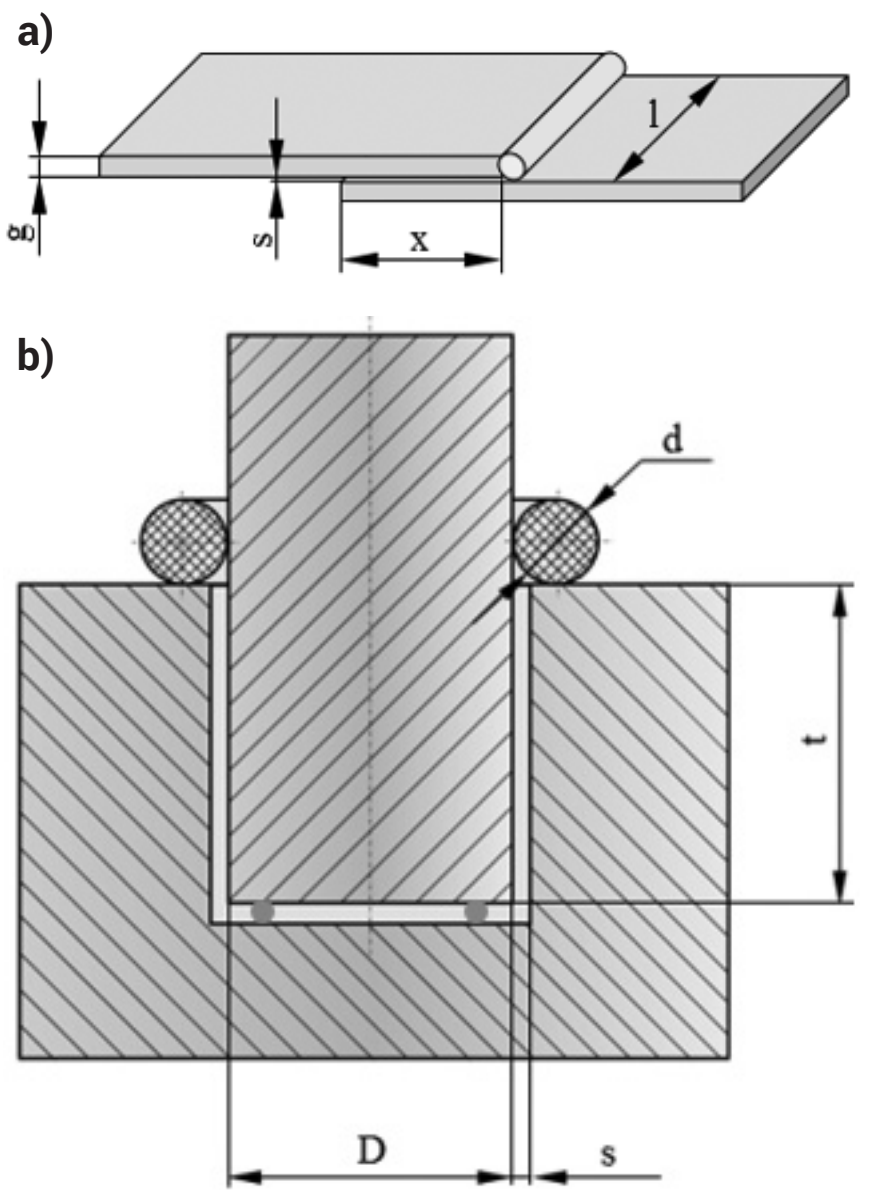

Rys. 9. Przygotowanie do lutowania: a) dla złącza zakładkowego, b) dla złącza z otworem nieprzelotowym

Fig. 9. Preparation for brazing: a) for the lap joint, b) for the joint with a blind hole

Do wykonania złącza zakładkowego użyto blaszek stalowych o wymiarach: szerokość l= $25 \mathrm{~mm}$ i grubość $\mathrm{g}=2 \mathrm{~mm}$. Długość zakładki (x) wyznaczona z równania: $\mathrm{X}=(3 \div 6) \mathrm{g}$ wynosiła $12 \mathrm{~mm}$ [9]. Szerokość szczeliny ustalono za pomocą stalowych drucików dystansowych o średnicy $0,2 \mathrm{~mm}$. Aby poprawnie wypełnić szczelinę lutowniczą przy użyciu spoiwa ułożonego tak jak na rysunku 9a, powinno ono mieć średnicę równą $2 \mathrm{~mm}$ [8]. Do obliczenia średnicy lutu w kształcie pierścionka użytego do wykonania złącza z otworem nieprzelotowym (rys. 9b), posłużono się wykresem przedstawionym na rysunku 10. Jak wynika z wykresu, do wypełnienia szczeliny lutowniczej (s) o szerokości 0,15 mm (na stronę) i długości zakładki (t) $12 \mathrm{~mm}$ (głębokość otworu nieprzelotowego) należy użyć lutu o średnicy (d) 1,5 mm. Wynik odczytany z wykresu potwierdzono również obliczeniami.

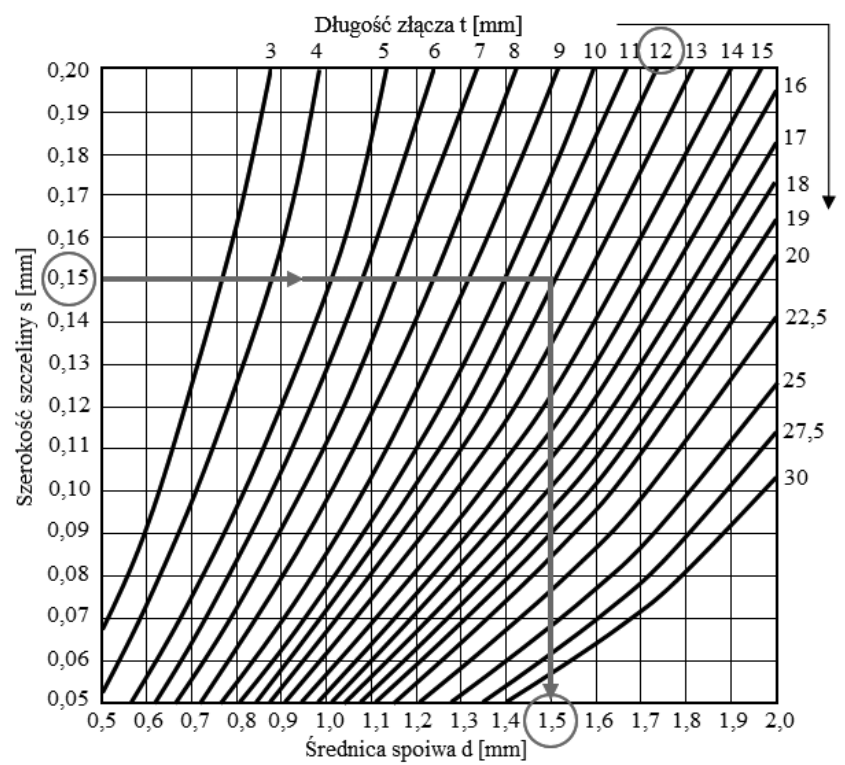

Rys. 10. Zależność średnicy spoiwa (d) od szerokości szczeliny (s) i długości złącza (t) [8]

Fig. 10. Dependence of braze diameter (d) on the width (s) and the joint length (t) [8]
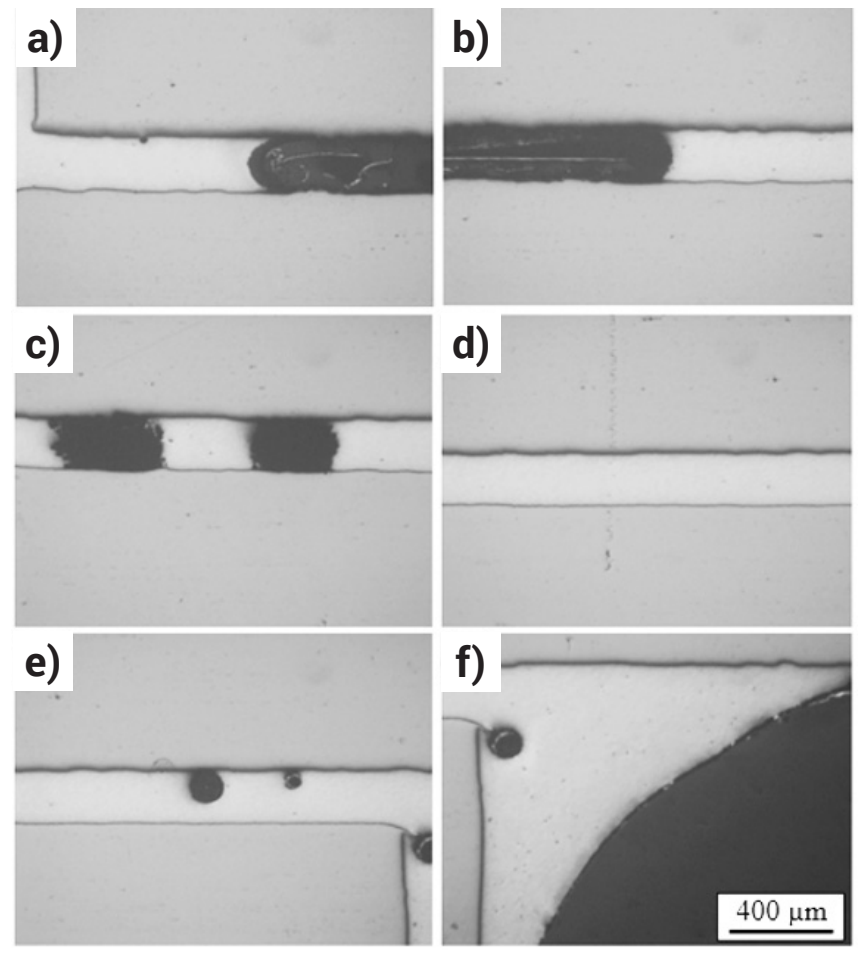

Rys. 11. Makrostruktura złącza stalowego wykonanego przy użyciu lutu Ag 244 i topnika TBB: a), b) i c) nieciągłości, d) poprawnie wykonany fragment złącza, e) i f) pęcherze gazowe

Fig. 11. Macrostructure of steel joint made with use Ag 244 braze and TBB flux: a), b) and c) discontinuities, d) correctly made fragment of joint, e) and f) gas pores 
Wykonane złącza przecięto $w$ połowie przy użyciu tarczy diamentowej i zainkludowano w żywicy epoksydowej. Przygotowane zgłady metalograficzne szlifowano na wodnych papierach ściernych o gradacji od 400 do 2400, a następnie polerowano przy użyciu diamentowej pasty polerskiej o wielkości ziarna $1 \mu \mathrm{m}$. Na rysunku 11 pokazano makrostrukturę złącza do wykonania którego użyto niewłaściwie dobrane materiały dodatkowe - lut Ag 244 i topnik TBB.

Niewłaściwe dopasowanie temperatury topnienia topnika i lutu powodują występowanie w lutowinie dużej ilości niezgodności lutowniczych. Występują nieciągłości (rys. 11a $\div 11 \mathrm{c}$ ) spowodowane pozostałościami żużla potopnikowego. Topnik osiągnął zbyt późno (w stosunku do lutu) temperaturę aktywności w związku z czym znaczna ilość jego pozostałości została uwięziona w lutowinie. Ponadto w lutowinie można zaobserwować niedużą ilość pęcherzy gazowych (rys. 11e i 11f) występujących po przeciwnej stronie złącza w stosunku do strony, z której podawany był lut.

Na rysunku 12 pokazano przekrój złącza lutowanego wykonanego przy użyciu lutu mosiężnego Cu 301 również w połączeniu z topnikiem TBB. W tym przypadku zakres temperatury topnienia obydwu materiałów dodatkowych dobrany był właściwie.
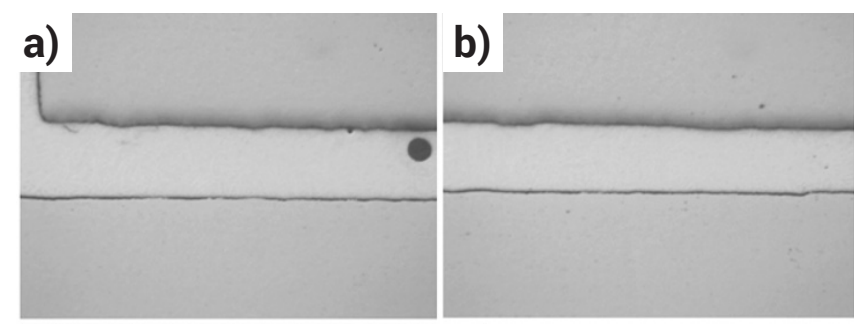

c)
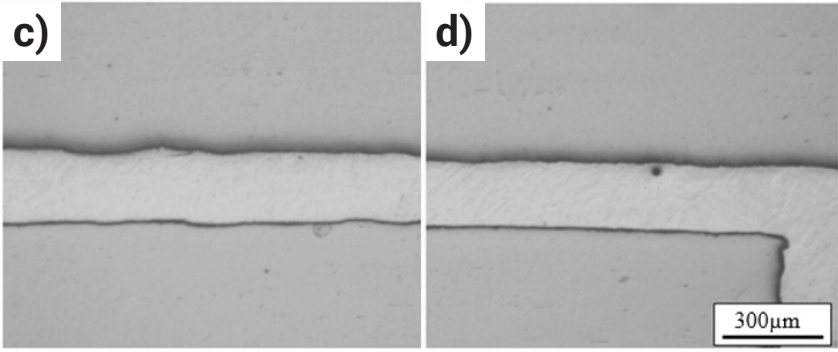

Rys. 12. Przekrój złącza stalowego wykonanego przy użyciu lutu Cu 301 i topnika TBB: a) i d) pęcherze gazowe, b) i c) poprawnie wykonany fragment złącza

Fig. 12. Cross section of steel joint made with use $\mathrm{Cu} 301$ braze and TBB flux: a) and d) gas pores), b) and c) correctly made fragment of joint

W przypadku prawidłowo dobranych względem siebie materiałów dodatkowych, w lutowinie występują tylko śladowe ilości niezgodności w postaci pęcherzy gazowych. Występują one na początku i na końcu złącza zakładkowego.

Złącza wykonane przy użyciu ekologicznego topnika Eco Smart Color Change nie wykazują niezgodności lutowniczych, zarówno w lutowinie utworzonej z lutu Ag 244 jak i Cu 301 (rys. 13 i 14). Z uwagi na stosunkowo szeroki zakres temperatur aktywności topnik ten dobrze nadaje się do lutowania z lutami na osnowie srebra i miedzi, stanowiących dużą grupę powszechnie stosowanych spoiw twardych.

Podobna sytuacja ma miejsce w przypadku złączy wykonanych przy użyciu topnika Eco Smart High Heat i spoiw Ag 244 i Cu 301 (rys. 15 i 16). Jedynie w lutowinie utworzonej

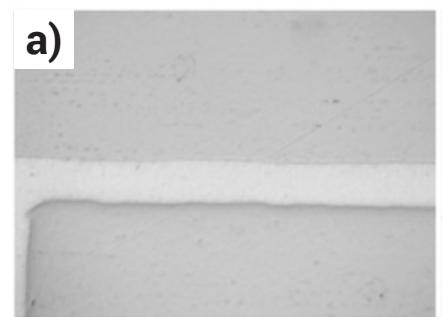

b)

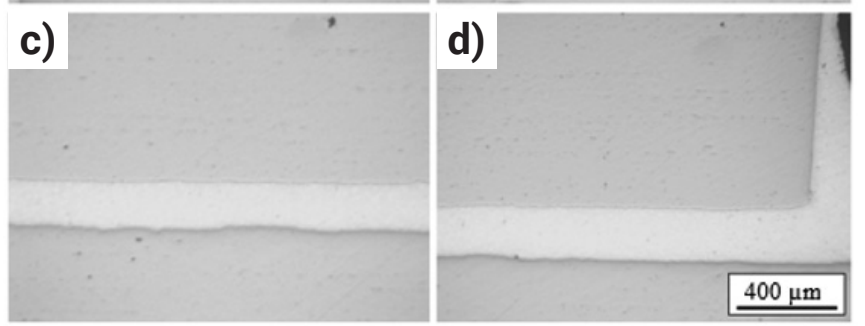

Rys. 13. Przekrój złącza stalowego wykonanego przy użyciu lutu Ag 244 i topnika Eco Smart Color Change - brak niezgodności lutowniczych

Fig. 13. Cross section of steel joint made with use Ag 244 braze and Eco Smart Color Change flux - incompliance brazing

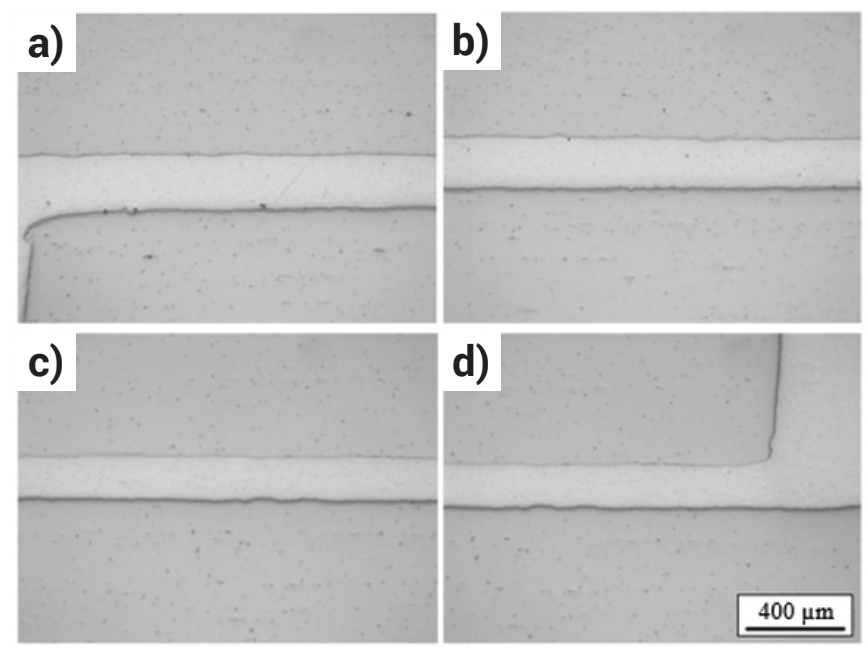

Rys. 14. Przekrój złącza stalowego wykonanego przy użyciu lutu Cu 301 i topnika Eco Smart Color Change - brak niezgodności lutowniczych

Fig. 14. Cross section of steel joint made with use $\mathrm{Cu} 301$ braze and Eco Smart Color Change flux - incompliance brazing

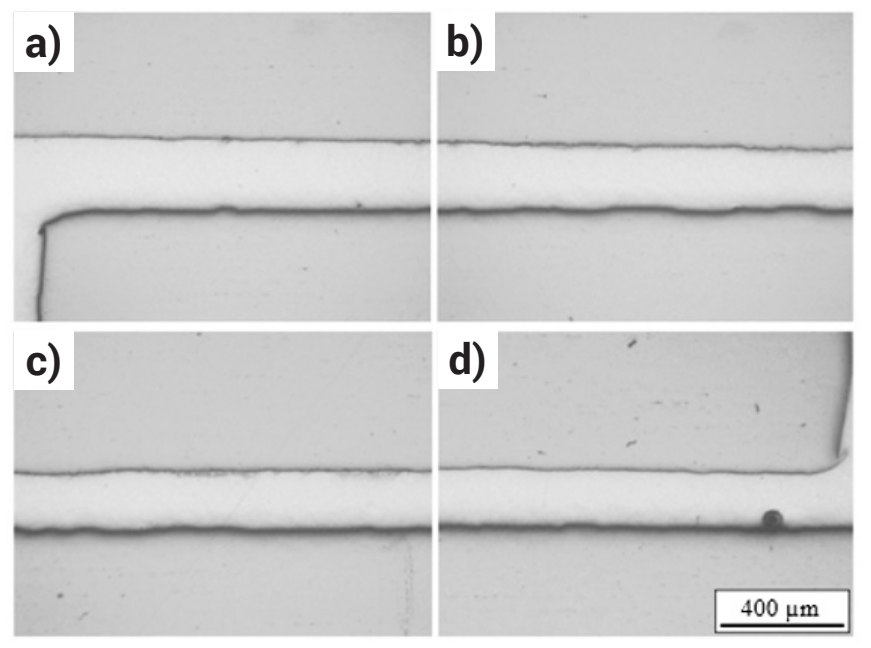

Rys. 15. Przekrój złącza stalowego wykonanego przy użyciu lutu Ag 244 i topnika Eco Smart High Heat: a) $\div$ c) brak niezgodności lutowniczych, d) pęcherz gazowy

Fig. 15. Cross section of steel joint made with use Ag 244 braze and Eco Smart High Heat flux: a) $\div$ c) incompliance brazing, d) gas pores 


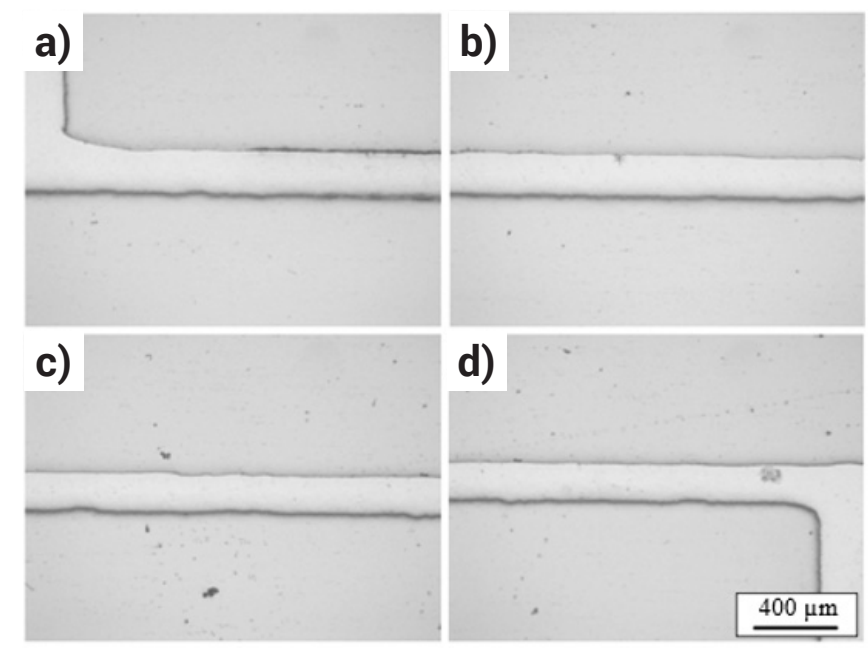

Rys. 16. Przekrój złącza stalowego wykonanego przy użyciu lutu $\mathrm{Cu}$ 301 i topnika Eco Smart High Heat - brak niezgodności lutowniczych Fig. 16. Cross section of steel joint made with use $\mathrm{Cu} 301$ braze and Eco Smart High Heat flux - incompliance brazing
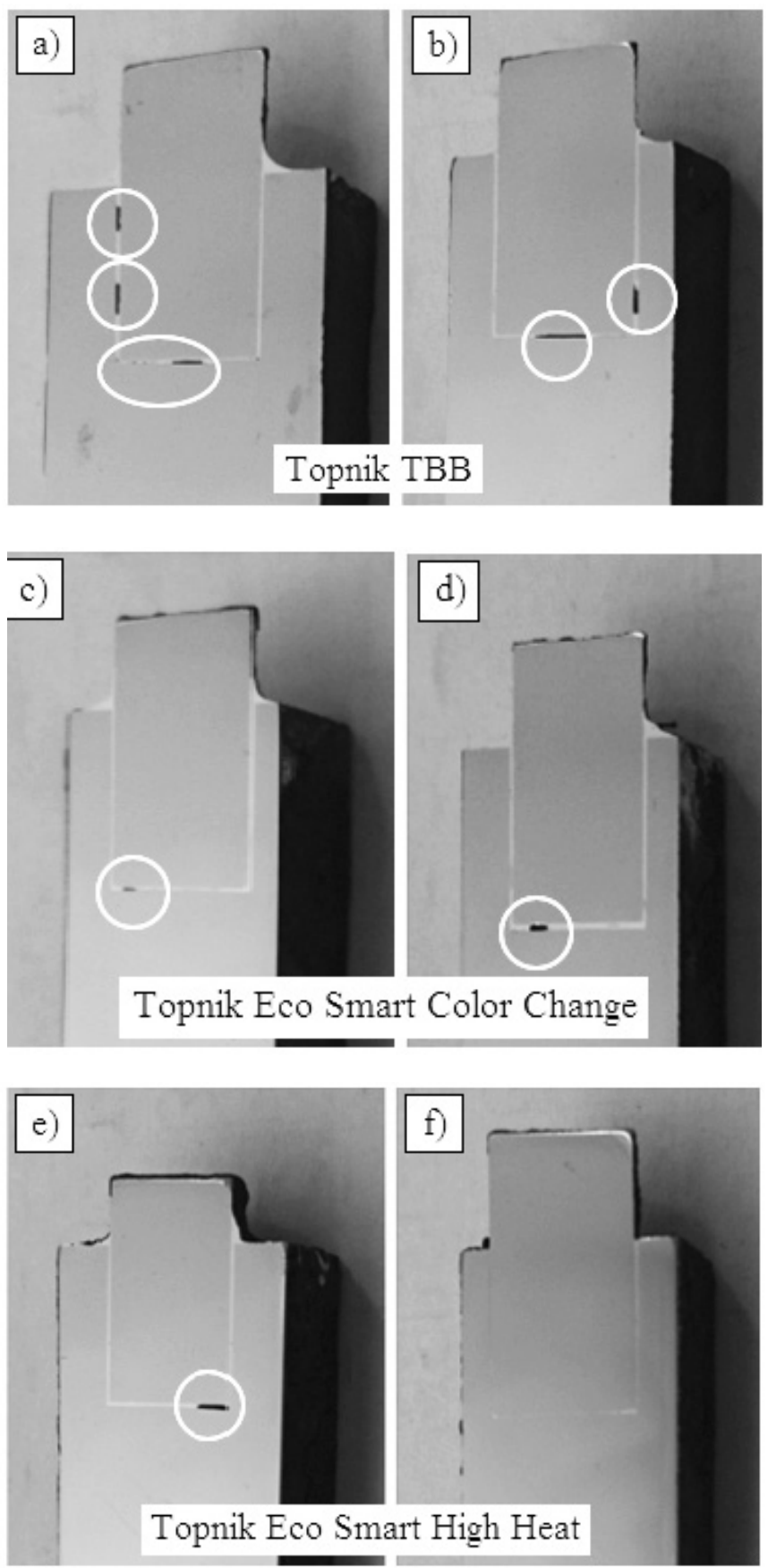

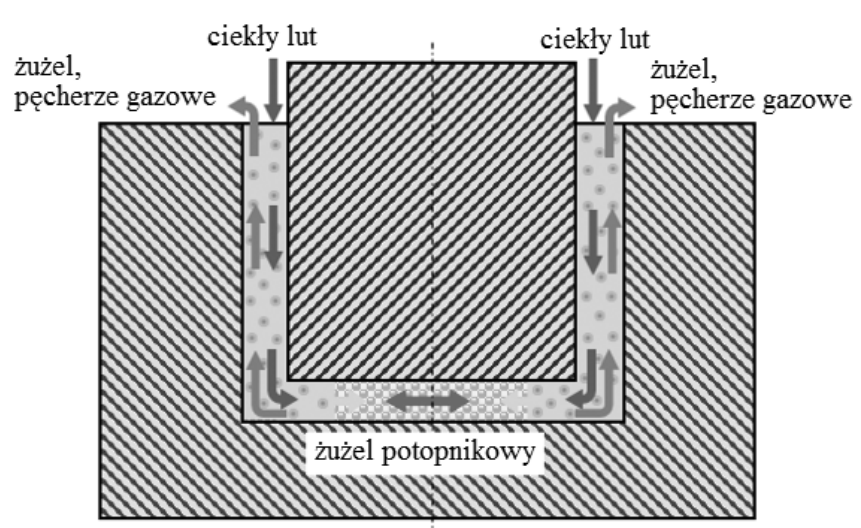

Rys. 18. Schemat wypełniania szczeliny lutowniczej przez ciekły lut w złączach z gniazdem zamkniętym

Fig. 18. Diagram of filling braze gap liquid solder in socket closed joints

z lutu srebrnego, po stronie przeciwnej do strony z której podawano lut, zauważyć można niewielki pęcherz gazowy (rys. $15 \mathrm{~d}$ ).

Badania metalograficzne wykonano również dla złączy z otworem nieprzelotowym - tzw. złączy nietechnologicznych. Na rysunku 17 pokazano makrostrukturę wykonanych próbek z zaznaczonymi fragmentami złącza, w których występują niezgodności lutownicze. Są to nieciągłości spowodowane pozostałościami żużla potopnikowego i niedolutowania.

Tylko w przypadku złącza wykonanego przy użyciu topnika Eco Smart High Heat w połączeniu z lutem mosiężnym nie stwierdzono żadnych niezgodności lutowniczych (rys. 17f). W pozostałych złączach wykonanych przy użyciu topników ekologicznych można zauważyć pewną prawidłowość - mianowicie nieciągłości występujące w lutowinie wypełniającej szczelinę przy dnie otworu (rys. 17c $\div 17 \mathrm{e}$ ). W przypadku złączy wykonanych przy użycia topnika na bazie boraksu i kwasu borowego (TBB) nieciągłości te występują również w lutowinie wypełniającej szczelinę przy powierzchni bocznej próbki (rys. 17a i 17b). Nieciągłości występujące w lutowinie przy dnie otworu spowodowane są pozostałościami żużla potopnikowego, który został uwięziony w lutowinie. Jak pokazano na rysunku 18 topnik oczyszczając chemicznie powierzchnię elementów lutowanych wydostaje się na zewnątrz w postaci żużli i pęcherzy gazowych. Część topnika, tworząca żużel potopnikowy, zostaje uwięziona w dolnej części złącza. Wytrzymałość mechaniczna takich złączy zależy w dużej mierze od prawidłowego wypełnienia szczeliny lutowniczej na obwodzie złącza, a nie od powierzchni czołowej. Dlatego nieciągłości występujące w złączach wykonanych przy użyciu topników ekologicznych nie powinny stanowić zmniejszenia ich funkcjonalności.

Rys. 17. Makrostruktura złączy stalowych z otworem nieprzelotowym wykonanych przy użyciu lutu srebrnego Ag 244 (a, c, e) i mosiężnego Cu 301 (b, d, f)

Fig. 17. Macrostructure of steel joint with a blind hole made with use Ag 244 silver braze (a, c, e) and Cu 301 brass braze $(b, d, f)$ 


\section{Wnioski}

Na podstawie przeprowadzonej analizy porównawczej topników ekologicznych z topnikiem na bazie boraksu i kwasu borowego, można sformułować następujące wnioski:

- topniki ekologiczne, z uwagi na szeroki zakres temperatury aktywności mogą być stosowane w procesach lutowania twardego z szeroką grupą lutów twardych - głównie na osnowie srebra i miedzi;

- topniki ekologiczne zapewniają bardzo dobre zwilżanie i rozpływanie się lutów twardych na badanych podłożach stalowych i miedzianych;

- pozostałości żużli z topników ekologicznych są stosunkowo łatwo rozpuszczalne w wodzie i są znacznie łatwiejsze do usunięcia w porównaniu z pozostałościami żużli potopnikowych na bazie boraksu i kwasu borowego. Ma to duże znaczenie w przypadku złączy o skomplikowanym kształcie;

- złącza wykonane przy użyciu topników ekologicznych charakteryzują się mniejszą ilością niezgodności lutowniczych w postaci pęcherzy gazowych i nieciągłości. Umożliwiają poprawne wykonanie złączy lutowanych o wysokiej jakości nie powodując przy tym zagrożenia dla zdrowia lutowaczy.

\section{Podziękowanie}

Autorzy artykułu składają serdeczne podziękowania dla firm: ALFA i EUROMAT z Wrocławia oraz HARRIS CALORIFIC INTERNATIONAL z Dzierżoniowa za udostępnienie materiałów dodatkowych do badań.

\section{Literatura}

[1] Mirski Z:: Spajanie węglików spiekanych ze stalą, Oficyna Wydawnicza Politechniki Wrocławskiej, Wrocław 2012.

[2] Nowacki J., Chudziński M., Zmitrowicz P.: Lutowanie w budowie maszyn, WNT, Warszawa 2007

[3] Pilarczyk J. (red.): Poradnik inżyniera. Spawalnictwo, tom 2, wyd. II, WNT, Warszawa 2014.

[4] Radomski T., Ciszewski A.: Lutowanie, WNT, Warszawa 1985.

[5] Rozporządzenie (WE) NR 1907/2006 Parlamentu Europejskiego i Rady $z$ dnia 18 grudnia 2006 r.

[6] www.harrisproductsgroup.eu

[7] www.alfasc.pl/topniki.html

[8] Zimmermann K.F: Das Löten mit Lotformteilen, Technik die verbindet, Berichte aus Forschung und Praxis, Degussa, zeszyt nr 11, Hanau 1975.

[9] Zimmermann K.F.: Lötgerechtes Konstruieren, Technik die verbindet, Berichte aus Forschung und Praxis, Degussa, zeszyt nr 9, Hanau 1975

[10] PN-EN ISO 17672:2010 Lutowanie twarde - Spoiwa.

[11] HARRIS: Poradnik lutowania miękkiego i twardego, Dzierżoniów 2016.
[12] Drzeniek H.: Nowe materiały lutownicze do lutowania miękkiego i twardego, referat, 4. Międzynarodowa Konferencja Lutownicza, 23-25 września 2013, Wrocław.

[13] Mirski Z., Granat K.: Topniki lotne - właściwości, zastosowanie i warunki bhp, Przegląd Spawalnictwa, nr 2-3/2007, s. 28-34.

[14] Mirski Z., Bulica A.: Topniki lotne. Właściwości i zastosowanie w instalacjach rurowych, Polski Instalator, nr 1/2005, s. 40-44.

[15] European Chemicals Agency: Recommendation of the European Chemicals Agency of 1 July 2015 for the inclusion of substances in Annex XIV to REACH (List of Substances subject to Authorisation), s. 1-9.

[16] Piwowarczyk T., Harapińska E., Wojdat T.: Trendy rozwojowe technologii lutowania i metod kontrolnych, Przegląd Spawalnictwa, nr 9/2016.

[17] Piwowarczyk T.: Projektowanie i wytwarzanie lutowanych ram rowerowych, Przegląd Spawalnictwa, nr 9/2016.

[18] Winiowski A., Majewski D.: Jakość w lutowaniu twardym i lutospawaniu - kwalifıkowanie technologii i personelu, metody badań, Przegląd Spawalnictwa, nr 9/2016. 